\title{
SCHOOL-BASED MANAGEMENT IN INDONESIAN BASIC EDUCATION: GOOD PRACTICES IN THE PAST
}

\author{
Laurens Kaluge \\ Kanjuruhan University, Indonesia \\ laurens@unikama.ac.id
}

\author{
Lilik Kustiani \\ Kanjuruhan University, Indonesia \\ lilikkustiani36@gmail.com
}

\begin{abstract}
Good practices of school-based management had been implemented in Indonesia almost two decades particular in basic education programs. However, it was still difficult to pinpoint certain program in a certain circumstances as the exemplary for others. The objectives were clarifying such kind of difficulties. This study compared the practices of nine programs at primary and junior secondary schools. Secondary data of 2420 respondents, from 15 districts in 7 provinces, were descriptively analyzed. The findings related to school planning, budgeting, information system, leadership, school climate, and school accountability. All these aspects appeared in those nine program. Most primary schools performed better than the upper education level. The results suggested for educational policies on continuous improvement in school management.
\end{abstract}

Keywords: good practice, school-based management, basic education, education program

\section{INTRODUCTION}

Plenty of evidences affirmed that good practices of school-based management (SBM) in educational development may constitute local wisdom or excellence. The results of initial reviews to the existing documents reporting on activities related to good practices as well as the supporting capacities indicated that some of those good practices need to be paid a very serious attention to be followed up by actions [1], [2], [3].

There were nine programs supposed to have good practices in SBM. In terms of the program characteristics, seven were related to SBM. [4] Those projects were Managing Basic Education (MBE), Regional Educational Development and Improvement Program - funded by Japanese Government (REDIPJICA), Regional Educational Development and Improvement Program - funded by Indonesian Government (REDIP-G), Decentralized Basic Education Project (DBEP), Creating Learning Community for Children (CLCC), Basic Education Project (BEP), Nusa Tenggara Timur Primary Education Partnership (NTT-PEP). The other two projects, Science Education Quality Improvement Project (SEQIP) and Contextual Teaching and Learning Program (CTL), were mainly focused on the teaching learning activities only.

Among the seven projects which had included the SBM components, their seven elements found to be their good practices [4], [5], [6]. Firstly, they established and empowered the school committee. Secondly, school development plan were required in the process of planning further activities for the incumbent year. Thirdly, the school development plan and school activities were always developed in participatory manner between the school and the community through, at least the involvement of school committee. Fourthly, they covered community expectation within the school development plan which reflected the intention of schools to interact with the local community and involve their needs in the school policy. Fifthly, school budget was developed by the team to ensure that the school could implement the planned activities of the program. Sixthly, monitoring and evaluation system were applied in the program to allow proper implementation of the implemented activities earlier planned. Seventhly, the reporting activities from the individual school to various parties were applied transparently.

In terms of differences, it could be identified that there was no significant difference among the seven projects regarding the good practices as well as their relevant aspects. In addition, from the documents reviewed it was found that in the enabling condition, training was the most dominant factor in determining the existence of good practices within the programs [7]. Due to the wide varieties of the trainings, not all of the training and workshop were covered within this article. However, to make sense of the existing trainings, they were going to be discussed on the basis of the training purposely for the implementation of the said good practices, directly prepared or designed by the individual project [8].

The purpose of most of the training was mainly to prepare the resource persons to enable the good practice in the area of SBM to be implemented properly following the scheme of the each project. In order to levelling the training, the resource persons were trained in the district or sub-district level, depended on the types of participants. In most cases, the training would require the involvement of school principals, teachers, and school committee members as the main participants. In the case of REDIP programs (REDIP-JICA and REDIP-G) the participants of the training were also school inspectors [9].

The similarities among the trainings provided to establish good practices in the area of SBM [10], [11] were: the levels and types of training. Within each of them the elements of objectives, duration of trainings, the resource persons or trainers involved, the resource materials used, the types and the number of participants in each type and level of training, the venues and the organizers of the training in conducting the training for similar purpose are scrutinized accordingly. 


\section{MeThods}

The main questions to be answered were developed as follows. First, what were the conditions that have led to the successful or unsuccessful implementation of the good practices in SBM? Second, what capacities allowed for the successful implementation of the good practices in the district down to the school level including community? Data used in this study were obtained from a project on Mainstreaming Good Practices in Basic Education operated by the South East Consortium for International Development (SECID) in Indonesia, funded by the European Commission.

The data represented schools, district, and provinces. For the mapping study, the selection of the target location of the study would be based on the six criteria. The first, the availability of the program offering the good practices within the nine programs discussed in the earlier parts in a province and its respective districts. The second, the number of programs offered in a certain province, district, and/or sub-district. The third, the availability of the schools where the good practices, from the nine programs, were implemented. The fourth, number of schools in the sub-district, number of sub-districts in the district, number of the districts in the province which implement good practices from certain programs. The fifth, specific sub-district or district which offered some good practices from which people can learn and be benefited from. The sixth, the readiness of the provinces, districts, sub-districts, and schools to be visited.

Data were collected from fifteen districts in seven provinces. The total respondents were 2420 teachers, 1401 represented primary schools (SD sekolah dasar) and the rest junior secondary schools (SMP - sekolah menengah pertama). The data were analysed descriptively, presented in graphs and supported by the qualitative data. Basically the comparison among projects was useful in order to answer the research questions by figuring out the salient good practices of related projects.

\section{Results}

Although, the SBM was specifically designed such as in MBE, REDIP-JICA, REDIP-G, DBEP, BEP, CLCC and NTT-PEP, the actual practices in field showed that all school samples had tried to implement it in various grasp of knowledge. Such kind of management had been socialized by the Ministry of Education and Culture through the program called Quality Improvement Using SBM (MPMBS manajemen peningkatan mutu berbasis sekolah). The following was the review of school-based management in view of school panning system, school budgeting system, leadership, information system, climate, and school accountability aspects.

\section{A. School Planning System}

Significant community involvement in the preparation of school development plan, which was carried through providing inputs to the school committee. Figure 1 illustrated that by the project, the most potential good practices of the community participation in school planning preparation was in MBE, NTT-PEP, and REDIP-JICA.

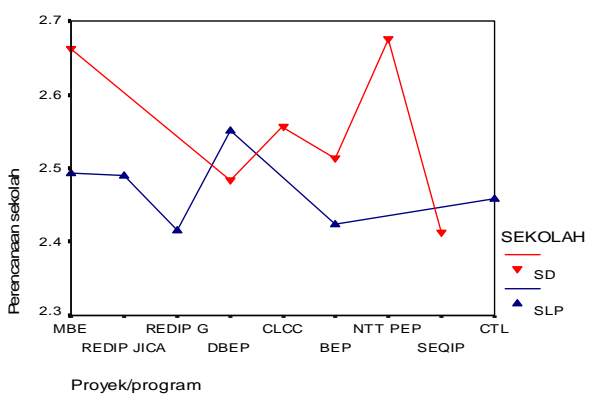

Figure 1 School Planning

With regard to education level, SD and SMP, it was clear that good practices in SD level were responded better than those of in SMP level. In SD level, the most potential community involvement in school planning forming good practices is shown in NTT PEP, MBE, and CLCC, while in SMP level the same is shown in DBEP, MBE, and REDIP JICA. Both description based on education level and district/kota, the community participation in SD level was better on average compared with those in SMP level.

\section{B. School Budgeting System}

School budgeting is related to the school development plan set forth in the SDP. Therefore, in Figure 2, the three projects for SD level i.e. MBE, CLCC, and BEP, and for SMP level i.e. BEP, REDIPJICA, and BEP address transparency aspect on budgeting apart from budgeting system. Budget is prepared based on the actual reality of different parties to be followed-up through SWOT analysis for further policy formulation. The community is required and encouraged to be involved in financing education as much as they are able. In view of local (district/kota) characteristics, there is consistency between the type of project and the location where the project is. Apart from the allocation set forth in School Budgeting Plan (RAPBS), transparency was addressed.

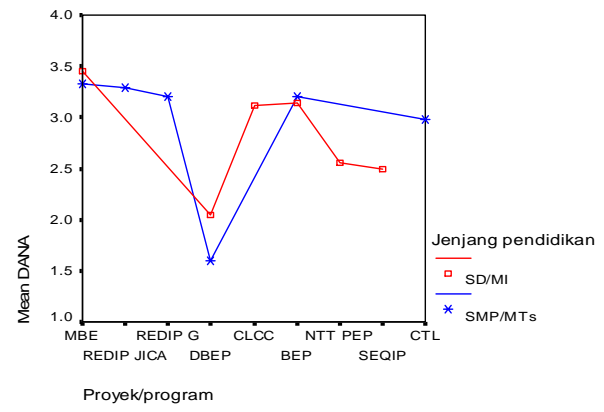

Figure 2 School Budgeting System

\section{Leadership}

In view of education level, as in Figure 3, it appeared that the leadership in SMP level was better 
in average than that in SD level. In SD level, the most potential good practices on leadership were shown in MBE, NTT PEP, and BEP, while in SMP level the same were shown in MBE, REDIP-JICA, and REDIPG. The potential good practices on leadership aspect analysed based on district/kota were different from those of analysed by project. On education level, it showed that leadership in SD level was better in average compared with those in SMP level.

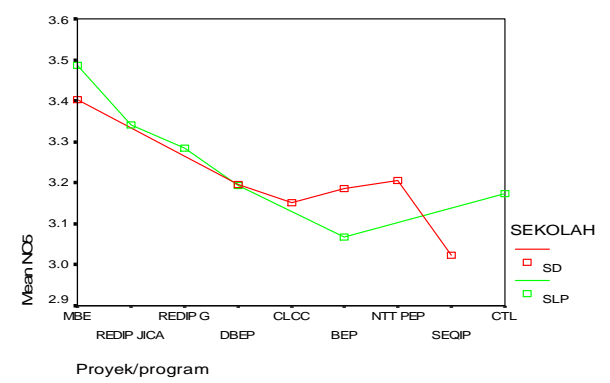

Figure 3 Leadership by Program and School Level

\section{Information System}

On information system at the school level, Figure 4 showed that SD level was better than SMP. In SDs, the projects that had most potential good practices on information system were NTT PEP, MBE, and BEP respectively, while in SMP level were REDIP G, DBEP, and CTL. The NTT-PEP had been developing intensive communication system between the school and community even, in fact, each kabupaten established the cooperation with local government's radio. Comparison among locations shows there was no significant differences between potential good practices for sub-componen of information system in SD and SMP level.

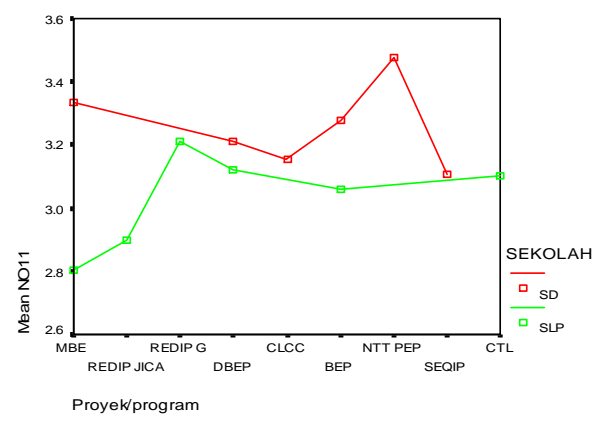

Figure 4 Information System

\section{E. School Climate}

Figure 5 illustrated that the high response to this sub-component was given by NTT-PEP, CLCC, and BEP. Special for NTT-PEP and CLCC, they introduced a motto called "friendly with children" that might have led to the school climate. Whereas in BEP, their focus on environmental rehabiliation program may also had led to the school climate in view of socio-psychological. The response to school climate based on education level in SD level was higher thant that in SMP. This because the complexity in SD level was lower compare with SMP level. The projects having high potential school climate in SD level were MBE, CLCC, and NTT-PEP respectively; while in SMP level they were REDIP-G, DBEP and CTL respectively. The illustration of school climate based on district's/kota's characteristics and education levels showed significant variation, especially in SMP level, although the average response of teachers to the school climate in SD level was higher than those in SMP.

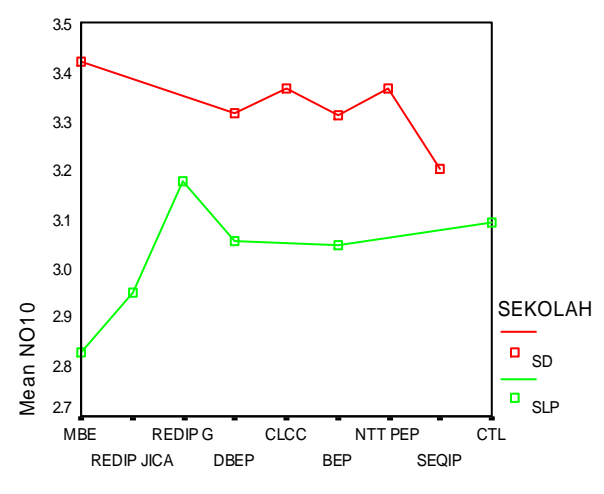

Proyek/program

Figure 5 School Climate

\section{F. School Acountability}

The responses to the school acountability, Figure 6, had been adequate in almost all projects and education levels. The reponse to the sub-component in SMP level was generally higher than those in SD level. In SD level, the projects having high potential school accountability were MBE, DBEP and NTT-PEP respectively; while in SMP level they were MBE, REDIP-G, and BEP. The improvement of school accountability was shown by the results of observation, for which almost all school samples post school financial reports on school bulletin board. This report included the total of budget, detailed expenditures, and the balance at certain time. The potential good practices of school accountability sub-component in view of education level is significantly varied among districts/kota.

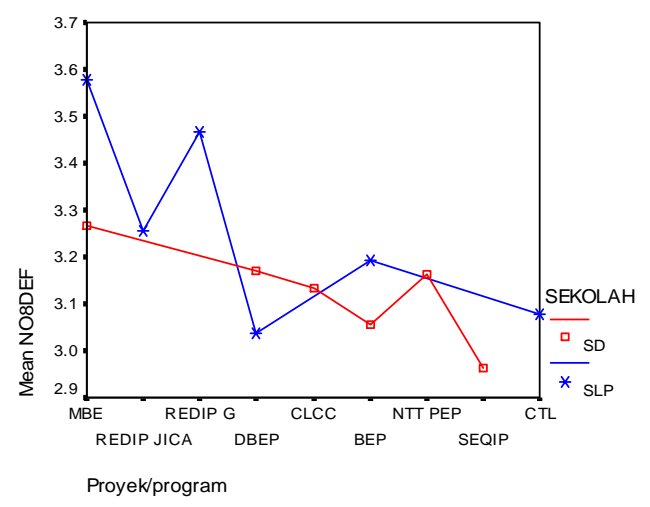

Figure 6 School Accountability

\section{Discussion}

By and large, the school development plan appeared in all programs at both SD and SMP levels. 
The plan itself took place due to the awareness of preparation process, the community involvement in many schools. This revealed that bottom-up planning process had been developed in school level [12].

For schools facilitated by MBE, the school committees were involved in the preparation, implementation, and monitoring/evaluation of SDP. The project used socio-cultural approach that encouraged local community and the school committee to support the school in forming ideas, manpower, and fund [13]. In the planning process it discussed various curricular and extracurricular programs, learning facilities, and the opportunity of community participation in education programs. In REDIP-JICA, the planning was the very vital process that should be proposed using "bottom-up" approach in effective and accurate manner for approval and implementation in the upper level of school. Therefore, the project developed a special training on proposal preparation. It was expected that the schools will be able to prepare good and adequate proposal in accordance with the criteria established. Similar to REDIP-JICA, BEP also motivate the whole parties relate to education since the planning stage.

The study conducted evaluation to the documents of planning (SDP) belong to the schools, and the results showed that school vision and mission were considered to be good, even, in fact, the observation in field showed that major schools post the vision and mission at the school gate [14]. The other component that was considered to be vital was the goals and objectives of school development plan, while the component having low potential good practices was monitoring and evaluation of school planning [15].

Moreover, MBE set up tighter policy requesting the schools and community to provide more fund for developing school sense of belonging and the appropriate use of fund [16]. The aspects of principal's leadership that were positively responded by respondents related to the principal's high expectation to the teacher's performance; the principal encouraged communities to acknowledge their aspiration and hoped in the future; while all school staff had equal opportunity to develop appropriate professionalism [10]. On the other hand, the lowest response was the involvement of non-teacher personnel in the preparation of school development plan. This reflects that the school gave less opportunity to non-teacher staff to participate in their school development.

Information system had potential good practices for the aspect of appropriate resolution of school problems. Generally most positive responses correlated with the accurate and effective internal communication within the school [17]. The school climate was indicated with the understanding of teacher and school staff to their responsibilities for the purpose of school development as positively responded by each school, followed by principal's determination of high expectation on teacher's performance, and giving the opportunity to all school personnel to develop relevant professionalism [18].
The school accountability [18], [11] was measured through education financing reports, parental understanding to the children performace without asking to the school, the awareness of the importance of community existence as the information sources, and regular financial reports.

\section{CONClusion}

Overall components of good practices of SBM took place in all projects in a wide variety, even in the projects, which designs were not to develop those components. Nothing perfectly happened, even progress has to be going on in all levels of basic education. The enabling capacities for good practices such as including the commitment of all related parties of provider and stakeholders of education, the availability of adequate regulations and human resources to support the emergence of good practices. The substances on school program, curriculum, personnel, children, resource and facilities, community support were the main ingredients for being improved. On the hand, the managerial aspects such as leadership, school climate, quality assurance, and initiatives were needed to consider into proper action.

\section{ACKNOWLEDGMENT}

This study reanalyzed data from SECID Project on Mainstreaming Good Practices in Basic Education, funded by the European Commision. We would like to thank for having access on the data set.

\section{REFERENCES}

[1] UNICEF-UNESCO. CLCC-Creating Learning Community for Children: Improving Primary Schools through School-Based Management and Community Participation (A Joint UNESCO-UNICEF-GOI Pilot Project): Evaluation Report. Jakarta 2000.

[2] Caldwell BJ, \& Spinks, J.M. Raising the Stakes - from improvement to transformation in the reform of schools. London: Routledge; 2008.

[3] Caldwell BJ. School Based Management (Manajemen Berbasis Sekolah). Paris: IIEP-UNESCO; 2006.

[4] Muljoatmodjo S. Task 1 Most Critical and Important Capacity Gaps in Basic Education". Progress Report 1 for UNICEF Jakarta2004.

[5] RTI-USAID. Managing Basic Education: Developing Local Government Capacity (An Introduction to the Program). Bulletin - May. Jakarta 2004.

[6] UNICEF. CLCC-Creating Learning Communities for Children: Second Progress Report to the Government of New Zealand. Jakarta 2004.

[7] Bergmann H, Whewell, E. Report of SEQIP Project Progress Review Jakarta 2001.

[8] UNICEF. CLCC-Creating Learning Communities for Children: A Project Proposal to AusAID. Jakarta 2003.

[9] MONE-JICA. The Study on Regional Educational Development and Improvement Program (Phase 2) in the Republic of Indonesia: Progress Report 4 Summary. Jakarta 2004.

[10] Caldwell BJ. Reconceptualizing the Self-managing School. Educational Management Administration \& Leadership. 2008;36(2):235-52.

[11] Mette IM, Ed Bengtson. Site-Based Management versus System-Based Thinking, the Impact of Data- 
Driven Accountability and Reform. Journal of Cases in Educational Leadership. 2015;18(1):27-38.

[12] Somech A. Directive Versus Participative Leadership: Two Complementary Approaches to Managing School Effectiveness. Educational Administration Quarterly. 2005;41(5):777-800.

[13] Prew M. Community Involvement in School Development Modifying School Improvement Concepts to the Needs of South African Township Schools. Educational Management Administration \& Leadership. 2009;37(6):824-46.

[14] Oterkiil C, Ertesvåg, S.K. Development of a measurement for transformational and transactional leadership in school taking on a school-based intervention. Educational Management Administration \& Leadership. 2014;42(2):5-27.

[15] Chang Z, Devos,G., Tondeur, J. Examining school culture in Flemish and Chinese primary schools. Educational Management Administration \& Leadership. 2013;42(4):557-75.

[16] Karsten S, Meijer,J. School-Based Management in the Netherlands: The Educational Consequences of LumpSum Funding. Educational Policy. 1999;13(3):421-39.

[17] Bauer SC, Bogotch, I.E. Modeling site-based decision making: School practices in the age of accountability. Journal of Educational Administration. 2006;44(5):446-70.

[18] Cheung SMC, Kan, F.L.F. Teachers' perceptions of Incorporated Management Committees as a form of school-based management in Hong Kong. Asia Pacific Education Review. 2009;10(2):139-48. 